Briliantini, et al/Jurnal Ekonomi Syariah Teori dan Terapan Vol. 6 No. 8 Agustus 2019: 1537-1552; ANALISIS HARGA SAHAM DAN EARNING PER SHARE (EPS) TERHADAP BID ASK SPREAD PADA SAHAM SYARIAH PERUSAHAAN PROPERTY DAN REAL ESTATE YANG TERDAFTAR DI ISSI PERIODE $2014-2017$

\title{
ANALISIS HARGA SAHAM DAN EARNING PER SHARE (EPS) TERHADAP BID ASK SPREAD PADA SAHAM SYARIAH PERUSAHAAN PROPERTY DAN REAL ESTATE YANG TERDAFTAR DI ISSI PERIODE $2014-20171$
}

\author{
Anggraeni Dwi Briliantini \\ Departemen Ekonomi Syariah - Fakultas Ekonomi dan Bisnis - Universitas Airlangga \\ Email: anggraenidb@gmail.com \\ Ari Prasetyo \\ Departemen Ekonomi Syariah - Fakultas Ekonomi dan Bisnis - Universitas Airlangga \\ Email: ari_feunair@yahoo.co.id
}

\begin{abstract}
:
This study aims to analyze the effect of stock prices and earnings per share on bid ask spread on sharia shares of property and real estate companies listed in ISSI for the period 2014-2017 both partially and horizontally. This study uses a population of property and real estate companies registered at the ISSI. This study uses a sample of 26 samples of property and real estate companies registered with the ISSI where the sampling technique uses purposive sampling technique. The observation period in this study starts from the period 2014 - 2017. Based on the results of the study, the best estimation model used is the common effect model (CEM), this indicates that the variable share price and earnings per share (EPS) have a significant and simultaneous influence towards bid ask spread of sharia shares of property and real estate companies registered in ISSI for the period 2014 - 2017. The results of the research partially indicate that the stock price variable has a significant negative effect on the bid ask spread of sharia stock property and real estate companies registered in the ISSI period 2014-2017, while the earnings per share (EPS) variable has no influence and is significant towards bid ask spread of sharia shares of property and real estate companies registered in ISSI for the period 2014 - 2017.
\end{abstract}

Keywords: Stock Price, Earning Per Share (EPS), property and real estate companies, ISSI

\section{PENDAHULUAN}

\section{Latar Belakang}

Kemajuan perekonomian di suatu negara dapat dilihat dari seberapa jauh perkembangan pasar modal suatu negara tersebut. Pasar modal merupakan suatu piranti yang memiliki peran penting dalam memajukan perekonomian negara. Tujuan dasar dari pasar modal itu sendiri adalah untuk menjembatani pihak yang memiliki kelebihan dana dengan pihak yang membutuhkan dana. Di era perekonomian yang modern ini banyak industri dan perusahaan yang sangat membutuhkan modal untuk mendorong keberlangsungan kinerja operasional perusahaan. Salah satu cara bagi perusahaan untuk memperoleh modal tambahan adalah dengan melakukan investasi pada pasar modal. Menurut Tandelilin (2010:2) investasi merupakan komitmen untuk mengeluarkan dana dengan mengorbankan konsumsinya pada saat ini, dengan tujuan memperoleh sejumlah keuntungan (return) dan

\footnotetext{
${ }^{1}$ Jurnal ini merupakan bagian dari skripsi Anggraeni Dwi Briliantini, NIM: 041511433082 , yang diuji pada tanggal 25 Juni 2019.
} 
Briliantini, et al/Jurnal Ekonomi Syariah Teori dan Terapan Vol. 6 No. 8 Agustus 2019: 1537-1552;

ANALISIS HARGA SAHAM DAN EARNING PER SHARE (EPS) TERHADAP BID ASK SPREAD PADA SAHAM SYARIAH PERUSAHAAN PROPERTY DAN REAL ESTATE YANG TERDAFTAR DI ISSI PERIODE $2014-2017$

tambahan pada masa datang dalam konsumsi.

Dalam Islam kegiatan investasi merupakan kegiatan yang sangat dianjurkan karena dengan berinvestasi, harta yang dimiliki akan lebih produktif dan mendatangkan manfaat bagi orang lain. Jika harta umat muslim didiamkan saja maka harta tersebut akan habis dari waktu ke waktu tanpa mendatangkan manfaat bagi diri sendiri maupun orang lain. Di era globalisasi ini banyak sekali perusahaan - perusahaan dan lembaga keuangan yang berbasis syariah. Hal ini tentunya sangat memberi kemudahan bagi umat muslim yang ingin berinvestasi tanpa adanya unsur riba.

Pasar modal di Indonesia setiap tahunnya mengalami perkembangan. Hal ini juga berimplikasi pada berkembangnya pasar modal berbasis syariah yang merupakan bagian dari industri keuangan syariah. Salah satu indeks pasar modal berbasis syariah yang digunakan oleh Bursa Efek Indonesia (BEI) adalah Indeks Saham Syariah Indonesia (ISSI). Indeks Saham Syariah Indonesia (ISSI) yaitu keseluruhan saham syariah yang terdaftar pada Bursa Efek Indonesia (BEI) dan tercatat di Daftar Efek Syariah (DES) yang diluncurkan pada tanggal $12 \mathrm{Mei}$ 2011.

Saham syariah merupakan salah satu instrument keuangan yang berbasis syariah pada kegiatan pasar modal. Menurut Hidayat (2011 : 78) saham syariah merupakan surat bukti kepemilikan atas sebagian perusahaan yang jenis usaha, produk barang, jasa yang diberikan, akad, dan serta pengelolaannya tidak bertentangan dengan prinsip - prinsip syariah.

Perkembangan perdagangan saham syariah ditunjukkan oleh nilai kapitalisasi pasar Indeks Saham Syariah Indonesia (ISSI). Nilai kapitalisasi pasar Indeks Saham Syariah Indonesia (ISSI) dibutuhkan untuk menggambarkan kinerja seluruh saham syariah yang terdaftar di Bursa Efek Indonesia (BEI), sedangkan dalam Jakarta Islamic Index (JII) hanya diwakili oleh 30 emiten yang penentuannya melibatkan dewan pengawas PT. Danareksa Investment Management. Perkembangan nilai kapitalisasi pasar Indeks Saham Syariah Indonesia (ISSI) dan Jakarta Islamic Index (JII) ditunjukkan dalam gambar sebagai berikut:

\begin{tabular}{|c|c|c|c|c|}
\hline & $\begin{array}{l}\text { KA } \\
\text { Tahun }\end{array}$ & $\begin{array}{l}\text { Jakarta Islamic } \\
\text { Index }\end{array}$ & $\begin{array}{l}\text { Indeks Saham Syariah } \\
\text { Indonesia }\end{array}$ & $\begin{array}{l}\text { Jakarta Islamic } \\
\text { Index } 70\end{array}$ \\
\hline \multicolumn{2}{|r|}{2000} & $74.268,92$ & - & - \\
\hline \multicolumn{2}{|r|}{2001} & $87.731,59$ & - & - \\
\hline \multicolumn{2}{|r|}{2002} & $92.070,49$ & - & - \\
\hline \multicolumn{2}{|r|}{2003} & $177.781,89$ & - & - \\
\hline \multicolumn{2}{|r|}{2004} & $263.863,34$ & - & - \\
\hline \multicolumn{2}{|r|}{2005} & $395.649,84$ & - & - \\
\hline \multicolumn{2}{|r|}{2006} & $620.165,31$ & - & - \\
\hline \multicolumn{2}{|r|}{2007} & $1.105 .897,25$ & - & - \\
\hline \multicolumn{2}{|r|}{2008} & $428.525,74$ & - & - \\
\hline \multicolumn{2}{|r|}{2009} & $937.919,08$ & - & - \\
\hline \multicolumn{2}{|r|}{2010} & $1.134 .632,00$ & - & - \\
\hline \multicolumn{2}{|r|}{2011} & $1.414 .983,81$ & $1.968 .091,37$ & - \\
\hline \multicolumn{2}{|r|}{2012} & $1.671 .004,23$ & $2.451 .334,37$ & - \\
\hline \multicolumn{2}{|r|}{2013} & 1.672.099,91 & $2.557 .846,77$ & - \\
\hline \multicolumn{2}{|r|}{2014} & $1.944 .531,70$ & $2.946 .892,79$ & - \\
\hline \multicolumn{2}{|r|}{2015} & $1.737 .290,98$ & $2.600 .850,72$ & - \\
\hline \multirow{2}{*}{\multicolumn{2}{|c|}{$\begin{array}{l}2016 \\
2017\end{array}$}} & $2.041 .070,80$ & $3.175 .053,04$ & - \\
\hline & & $2.288 .015,67$ & $3.704 .543,09$ & - \\
\hline \multirow[t]{7}{*}{2018} & Januari & $2.372 .953,33$ & $3.854 .741,68$ & - \\
\hline & Februari & 2.327.226,90 & $3.821 .640,52$ & - \\
\hline & Maret & $2.123 .498,74$ & $3.584 .600,83$ & - \\
\hline & April & $2.090 .206,97$ & $3.535 .242,35$ & - \\
\hline & Mei & $2.037 .051,21$ & $3.481 .101,67$ & $2.575 .667,69$ \\
\hline & Juni & $2.047 .165,04$ & $3.427 .582,42$ & $2.510 .032,86$ \\
\hline & Juli & $2.048 .117,46$ & $3.518 .381,21$ & $2.526 .844,32$ \\
\hline
\end{tabular}


Briliantini, et al/Jurnal Ekonomi Syariah Teori dan Terapan Vol. 6 No. 8 Agustus 2019: 1537-1552;

ANALISIS HARGA SAHAM DAN EARNING PER SHARE (EPS) TERHADAP BID ASK SPREAD PADA SAHAM SYARIAH PERUSAHAAN PROPERTY DAN REAL ESTATE YANG TERDAFTAR DI ISSI PERIODE $2014-2017$

Sumber :Otoritas Jasa Kevangan

\section{Gambar 1}

\section{Perkembangan Nilai Kapitalisasi Pasar} pada Bursa Efek Indonesia Tahun 2011 2017

Kapitalisasi pasar merupakan nilai perusahaan yang dihitung dari jumlah seluruh saham perusahaan beredar dikalikan dengan harga pasar saham, dengan demikian semakin mahal harga saham maka semakin tinggi nilai kapitalisasinya. Jika dilihat dari nilai kapitalisasi gambar diatas saham - saham syariah menunjukkan peningkatan yang stabil, hal ini mengindikasikan kondisi makro ekonomi yang baik bagi peningkatan kinerja perusahaan. Dilihat dari fungsi ekonomi, meningkatnya nilai kapitalisasi saham syariah menunjukkan keberhasilan pasar modal syariah sebagai pengumpul sumber dana alternative bagi investasi perusahaan yang berlandaskan prinsip syariah.

Dalam pasar modal terdapat berbagai macam sektor saham syariah yang tersedia, salah satunya yaitu sektor property dan real estate. Sektor property dan real estate merupakan salah satu sektor yang terus mengalami perkembangan. Pertumbuhan jumlah penduduk yang meningkat menyebabkan kebutuhan akan sektor property dan real estate mengalami kenaikan, sehingga hal ini menyebabkan sektor property dan real estate bertumbuh dengan sangat pesat. Bisnis property dan real estate merupakan bisnis yang dikenal memiliki karakteristik cepat berubah (volatile) dengan persaingan yang sangat ketat. Banyak masyarakat yang menginvestasikan modalnya pada sektor property dan real estate, ini dikarenakan harga tanah yang cenderung meningkat setiap tahunnya. Penyebab dari harga tanah yang cenderung meningkat adalah ketersediaan tanah bersifat tetap sedangkan permintaan akan tanah tersebut cenderung meningkat seiring denga pesatnya pertumbuhan penduduk. Menurut Husnan (2009 : 325) perusahaan property dan real estate merupakan industri yang peka terhadap perkembangan suku bunga dan hal ini terbukti dengan adanya penurunan harga saham. Investasi pada bidang property dan real estate pada umumnya bersifat jangka panjang dan akan terus bertumbuh sejalan dengan pertumbuhan ekonomi serta investasi pada sektor ini merupakan salah satu investasi yang menjanjikan Dalam melakukan kegiatan investasi, seorang investor memerlukan sejumlah informasi yang berkaitan dengan pergerakan harga saham agar bisa mengambil keputusan tentang saham perusahaan yang layak untuk dipilih. Pengetahuan bid ask spread sangat diperlukan bagi investor terutama investor yang mengharapkan capital gain, karena hal ini merupakan suatu komponen biaya dalam perdagangan saham. Namun pada umumnya para investor kurang 
Briliantini, et al/Jurnal Ekonomi Syariah Teori dan Terapan Vol. 6 No. 8 Agustus 2019: 1537-1552; ANALISIS HARGA SAHAM DAN EARNING PER SHARE (EPS) TERHADAP BID ASK SPREAD PADA SAHAM SYARIAH PERUSAHAAN PROPERTY DAN REAL ESTATE YANG TERDAFTAR DI ISSI PERIODE $2014-2017$

memperhatikan perilaku bid ask spread, padahal perubahan bid ask spread saham memberikan banyak informasi bagi investor tentang return saham, risiko saham, dan lain - lain, dengan cara melihat spread yang dihasilkan dari suatu perusahaan yang akan dibelinya.

Bid ask spread adalah selisih harga beli tertinggi dan harga jual terendah atas suatu saham. Bid Price merupakan harga tertinggi yang ditawarkan oleh broker/dealer atau harga dimana broker/dealer menawar untuk membeli saham, sedangkan ask spread merupakan harga terendah dimana broker/dealer bersedia untuk menjual saham. Stoll (1989) dalam Eprilia (2017) menyatakan bahwa bid ask spread merupakan fungsi dari tiga komponen biaya yang berasal dari biaya pemilikan saham (inventory holding cost), biaya pemrosesan (order processing cost) dan biaya informasi yang merugikan (adverse information cost). Biaya kepemilikan saham terdiri dari risiko harga dan opportunity cost yang dihubungkan dengan pemilik saham. Biaya pemrosesan berhubungan dengan biaya untuk mengatur perdagangan, pencatatan transaksi, administrasi, telepon, dan sebagainya. Sedangkan biaya informasi asimetri adalah biaya yang timbul karena adanya informasi yang tidak dapat didistribusikan secara merata kepada semua pelaku di pasar modal. Adanya perbedaan dalam mendapatkan informasi tersebut menyebabkan terjadinya risiko kerugian yang dicerminkan oleh bid ask spread. Berikut ini adalah gambar perkembangan bid ask spread periode 2012 - 2017. Terlihat pada tabel bahwa pada tahun 2012 - 2017 di pasar modal Indonesia terjadi kenaikan dan penurunan nilai bid ask spread saham. Terjadinya penurunan dan kenaikan bid ask spread ini disebabkan oleh berbagai faktor (leverage, return, dan lain-lain).

\begin{tabular}{|l|r}
\multicolumn{1}{|c|}{ Periode } & Bid-Ask Spread \\
\hline 2012 & 3.94 \\
2013 & 4.18 \\
2014 & 3.82 \\
2015 & 3.99 \\
2016 & 3.10 \\
2017 & 3.51 \\
\hline
\end{tabular}

Sumber :Otoritas Jasa Keuangan (Statistik pasar modal 2017)

Gambar 2

Perkembangan Rata - rata bid ask spread pada Bursa Efek Indonesia periode 2012 2017

\section{Rumusan Masalah}

Berdasarkan uraian latar belakang di atas maka peneliti merumuskan masalah apakah harga saham, earning per share (EPS) dan varian return saham mempunyai pengaruh terhadap bid ask spread saham syariah perusahaan property dan real estate periode 2014 - 2017 secara parsial dan simultan?

\section{Tujuan Penelitian}

Berdasarkan rumusan masalah yang ditetapkan di atas, maka tujuan 
Briliantini, et al/Jurnal Ekonomi Syariah Teori dan Terapan Vol. 6 No. 8 Agustus 2019: 1537-1552; ANALISIS HARGA SAHAM DAN EARNING PER SHARE (EPS) TERHADAP BID ASK SPREAD PADA SAHAM SYARIAH PERUSAHAAN PROPERTY DAN REAL ESTATE YANG TERDAFTAR DI ISSI PERIODE $2014-2017$

penelitian ini adalah untuk mengetahui apakah variabel harga saham, earning per share dan varian return saham memiliki pengaruh secara parsial dan simultan terhadap bid ask spread saham syariah perusahaan property dan real estate periode 2014 - 2017.

\section{LANDASAN TEORI}

Investasi merupakan kata adopsi dari bahasa inggris, yaitu investment. Kata invest merupakan kata dasar dari investment yang mempunyai arti menanam. Menurut Tandelilin (2010:2), investasi mempunyai arti sebagai komitmen atas pengeluaran sejumlah dana atau sumber daya lainnya yang dimiliki investor atau perusahaan pada masa sekarang dengan tujuan memperoleh keuntungan di masa yang akan datang. Ryandono (2009:21) menyampaikan bahwa investasi yang islami merupakan pengorbanan sumberdaya yang dimiliki pada masa sekarang untuk mendapatkan hasil yang pasti, dengan harapan memperoleh hasil yang lebih besar dimasa yang akan datang, baik secara langsung maupun tidak langsung dengan tetap berpijak pada prinsip - prinsip syariah Islam secara menyeluruh. Selain itu, segala bentuk investasi yang dilakukan harus dalam rangka ibadah kepada Allah untuk mencapai kebahagiaan lahir batin di dunia dan akhirat, baik bagi generasi pada masa sekarang maupun generasi yang akan datang. Penjelasan diatas juga telah dijelaskan dalam surat Al - Luqman ayat 34 sebagai berikut :

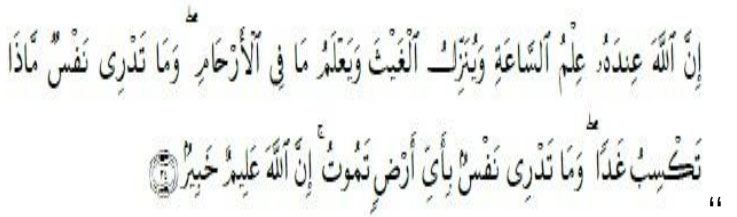

Innallāha 'indahụ 'ilmus-sā'ati, wa yunazzilul-gaīsa, wa ya'lamu mā fil-arḥāmi, wa mā tadrī nafsum māżā taksibu gadā, wa mā tadri nafsum bi ayyi arḍin tamụt, innallāha 'alimun khabīr"

"Sesungguhnya Allah, hanya pada sisi-Nya sajalah pengetahuan tentang hari kiamat; dan Dialah yang menurunkan hujan, dan mengetahui apa yang ada dalam rahim. Dan tiada seorang pun yang dapat mengetahui dengan pasti apa yang akan diusahakan besok. Dan tiada seorang pun yang dapat mengetahui di bumi mana dia akan mati. Sesungguhnya Allah Maha Mengetahui lagi Maha Mengenal." (Q.S. Al - Luqman : 34) (Departemen Agama, 2005:648)

Ayat di atas menurut Shihab (2002:342) dalam tafsir Al - Mishbah bahwa Allah mengetahui segala sesuatu, sedangkan manusia tidak mengetahui segala sesuatu. Ada beberapa hal yang bisa diketahui oleh manusia melalui ilmu dan pengetahuan. Ilmu Allah terdapat kejelasan, bukan dari hasil sesuatu, mengetahui tanpa alat bantu. Sebaliknya dengan berkat Allah manusia bisa meraih ilmu dan pengetahuan.

\section{Bid Ask Spread}


Briliantini, et al/Jurnal Ekonomi Syariah Teori dan Terapan Vol. 6 No. 8 Agustus 2019: 1537-1552; ANALISIS HARGA SAHAM DAN EARNING PER SHARE (EPS) TERHADAP BID ASK SPREAD PADA SAHAM SYARIAH PERUSAHAAN PROPERTY DAN REAL ESTATE YANG TERDAFTAR DI ISSI PERIODE $2014-2017$

Karakteristik penting suatu pasar keuangan yang terorganisir yang banyak dicari para investor adalah likuiditas, kemampuan dalam membeli atau menjual sekuritas secara cepat. Dalam hal ini banyak bursa menggunakan market maker untuk memelihara likuiditas. Market maker itu sendiri adalah pihak-pihak yang bersedia dalam hal membeli dan menjual saham kapanpun kepada public. Sebagai salah satu partisipan pasar modal, market maker atau dealer harus menghadapi masalah yang berkaitan dengan keagenan, hal ini dikarenakan adanya ketidak seimbangan informasi atau yang biasa disebut information asymmetry.

\section{Harga Saham}

Harga saham adalah surat tanda kepemilikan sebagian perusahaan. harga saham adalah harga yang terbentuk di pasar dan tercatat setiap hari pada waktu penutupan (closing price). Besarnya harga saham yang terbentuk dipasar dipengaruhi oleh hukum permintaan dan penawaran. Sartono (2001: 2) menyatakan bahwa harga pasar saham terbentuk melalui mekanisme permintaan dan penawaran yang ada di pasar modal. Sedangkan menurut Rasyidi dan Murdayanti (2013) menyatakan bahwa terbentuknya harga pasar saham dapat diukur dari harga resmi berdasarkan transaksi terakhir pada hari bursa. Closing price suatu saham dalam satu hari perdagangan ditentukan pada akhir sesi II yaitu pukul 4 sore.
Salah satu indikator keberhasilan pengelolaan perusahaan adalah harga saham, dimana kekuatan pasar ditunjukkan dengan terjadinya transaksi perdagangan saham pada pasar modal. Kemajuan dan kemunduran perusahaan akan direspon oleh pasar melalui perubahan harga saham (Samsul, 2015 : 189). Perusahaan akan menerima capital gain apabila saham yang diperjualbelikan di pasar modal memiliki harga tinggi. Selain memperoleh capital gain, perusahaan juga akan mendapat citra yang baik dimata investor sehingga memudahkan manajemen perusahaan dalam mendapatkan dana eksternal.

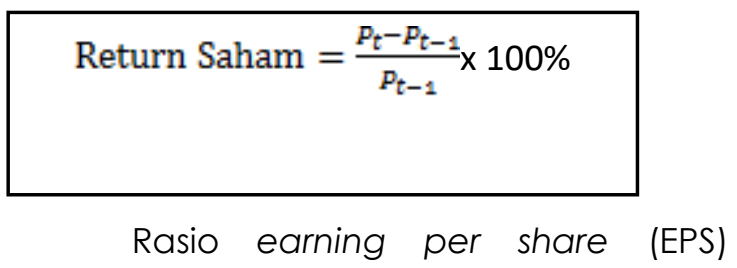
merupakan rasio yang digunakan untuk mengukur besarnya laba bersih atau pendapatan bersih yang diperoleh perusahaan dari setiap lembar saham. Earning per share (EPS) merupakan rasio yang menggambarkan keadaan profitabilitas perusahaan. Semakin tinggi nilai earning per share (EPS) maka pendapatan laba perusahaan akan semakin besar, sehingga akan terjadi peningkatan jumlah deviden yang diterima oleh para pemegang saham. Besarnya earning per share (EPS) suatu perusahaan dapat diketahui atau di lihat dari laporan keuangan perusahaan, jika perusahaan tidak menerbitkan atau tidak 
Briliantini, et al/Jurnal Ekonomi Syariah Teori dan Terapan Vol. 6 No. 8 Agustus 2019: 1537-1552; ANALISIS HARGA SAHAM DAN EARNING PER SHARE (EPS) TERHADAP BID ASK SPREAD PADA SAHAM SYARIAH PERUSAHAAN PROPERTY DAN REAL ESTATE YANG TERDAFTAR DI ISSI PERIODE $2014-2017$

mencantumkan besarnya nilai earning per share (EPS) maka para calon investor bisa melihat informasi earning per share (EPS) melalui laporan neraca dan laporan laba/rugi perusahaan (Tandelilin, 2001 : 242).

Earning Per Share $=\frac{\text { Laba bersih setelah pajak }}{\text { Jumlah saham beredar }}$

\section{Varian Return}

Fitriyah (2012) menyatakan bahwa varian return menunjukkan variabilitas return diseputar return normal yang diakibatkan adanya volatilitas (fluktuasi harga) saham. Sedangkan menurut Leoni dan Yunika (2013), varian return adalah rata - rata varian dari return harian selama satu tahun. Return harian adalah presentase perubahan harga penutupan saham pada periode $\dagger$ dengan harga penutupan saham pada periode $\dagger$ sebelumnya. Return saham dirumuskan sebagai berikut :

Keterangan :

$\mathrm{P}_{\dagger} \quad=$ Harga penutupan saham pada periode $\dagger$

$\mathrm{P}_{\mathrm{t}-1}=$ Harga penutupan saham pada periode $\mathrm{t}-1$

Varian return adalah tingkat risiko yang terjadi atas investasi yang dilakukan, terutama akibat transaksi saham di pasar bursa yang disebabkan oleh volatilitas harga saham. Varian return dalam hal ini mewakili risiko saham yang dapat mempengaruhi besar kecilnya saham. Semakin tinggi varian return menunjukkan semakin bervariasinya return harian yang diperoleh investor. Varian return saham juga menunjukkan risiko saham yang dihadapi oleh dealer. Semakin tinggi risiko saham yag dihadapi dealer menyebabkan dealer berusaha menutupinya dengan spread yang lebih besar (Ambarwati, 2008 : 31). Varian return merupakan kuadrat dari standar deviasi. Mengacu pada penelitian Dira (2015), varian return dirumuskan sebagai berikut:

$$
\sigma_{i}^{2} \frac{\sum_{t}^{N}=\left(P_{t}-\overline{P t}\right)^{2}}{n-1}
$$

Hubungan Harga Saham terhadap Bid Ask Spread

Harga saham merupakan harga terakhir suatu saham (closing price) pada perdagangan harian saham yang terbentuk karena adanya interaksi dari para penjual dan pembeli saham. Dalam mengambil keputusan informasi terkait pergerakan harga saham sangatlah dibutuhkan oleh para investor. Hal ini dikarenakan informasi tersebut dapat mengurangi risiko ketidakpastian yang terjadi, sehingga keputusan yang diambil investor diharapkan dapat sesuai dengan tujuan yang diinginkan. Harga saham dalam hal ini sangat dipengaruhi oleh hukum permintaan dan penawaran, dimana jika permintaan saham akan suatu perusahaan lebih besar daripada kuantitas saham yang ditawarkan maka harga saham perusahaan tersebut akan mengalami peningkatan atau kenaikan, begitu juga sebaliknya apabila 
Briliantini, et al/Jurnal Ekonomi Syariah Teori dan Terapan Vol. 6 No. 8 Agustus 2019: 1537-1552; ANALISIS HARGA SAHAM DAN EARNING PER SHARE (EPS) TERHADAP BID ASK SPREAD PADA SAHAM SYARIAH PERUSAHAAN PROPERTY DAN REAL ESTATE YANG TERDAFTAR DI ISSI PERIODE $2014-2017$

permintaan saham akan suatu perusahaan lebih kecil daripada kuantitas saham yang ditawarkan maka harga saham perusahaan tersebut akan mengalami penurunan.

Beaver dalam Ewijaya (1999: 56) menyatakan bahwa infomasi terkait harga saham merupakan salah satu faktor penting bagi investor, karena perubahan harga saham dapat mengakibatkan perubahan perilaku konsumsi para pelaku pasar modal atau investor. Jika harga saham suatu perusahaan tersebut naik maka saham tersebut aktif diperdagangkan sehingga investor tidak perlu terlalu lama memegang saham tersebut sehingga dapat menurunkan bid ask spread. Sebaliknya, jika harga saham perusahaan tersebut turun maka saham tersebut tidak aktif diperdagangkan sehingga investor akan menahan lebih lama saham tersebut yang dapat mengakibatkan turunnya bid ask spread saham perusahaan tersebut.

\section{Hubungan Earning Per Share terhadap Bid}

\section{Ask Spread}

Earning Per Share (EPS) merupakan rasio yang menggambarkan profitabilitas perusahaan yang tergambar pada setiap lembar saham. Tambunan (2007:117) mengatakan bahwa pemegang saham atau investor dapat mengetahui besar keuntungan yang diperoleh dari tiap lembar saham melalui informasi pendapatan laba per lembar saham perusahaan tersebut. Semakin tinggi nilai earning per share (EPS) perusahaan maka semakin tinggi pula minat investor dalam berinvestasi pada perusahaan tersebut. Begitu juga sebaliknya, jika nilai earning per share (EPS) perusahaan menurun maka saham perusahaan tersebut kurang diminati oleh para investor. Perusahaan disebut memiliki prospek yang bagus ketika perusahaan tersebut memiliki nilai Earning Per Share (EPS) yang tinggi. Nilai Earning Per Share (EPS) saham yang tinggi mengartikan bahwa saham perusahaan tersebut aktif diperdagangkan. Apabila suatu saham aktif diperdagangkan maka dealer tidak akan memegang saham tersebut terlalu lama yang mengakibatkan penurunan biaya kepemilikan dan menurunkan tingkat bid ask spread saham tersebut.

$$
\text { Penelitian Eprilia }
$$
menyatakan bahwa variabel earning per share (EPS) mempunyai pengaruh yang negatif dan tidak signifikan terhadap bid ask spread saham syariah perusahaan yang terdaftar Indeks Saham Syariah Indonesia (ISSI) periode 2013 - 2015. Hal ini mencermikan bahwa tinggi rendahnya nilai earning per share (EPS) suatu perusahaan tidak akan mempengaruhi nilai turunnya bid ask spread saham. Variabel earning per share (EPS) cenderung relatif statis sehingga pengaruhnya terhadap bid ask spread saham syariah tidak signifikan.

Hubungan Varian Return terhadap Bid Ask Spread 
Briliantini, et al/Jurnal Ekonomi Syariah Teori dan Terapan Vol. 6 No. 8 Agustus 2019: 1537-1552; ANALISIS HARGA SAHAM DAN EARNING PER SHARE (EPS) TERHADAP BID ASK SPREAD PADA SAHAM SYARIAH PERUSAHAAN PROPERTY DAN REAL ESTATE YANG TERDAFTAR DI ISSI PERIODE $2014-2017$

Varian return merupakan tingkat variabilitas dari return suatu saham. Jika return saham menunjukkan banyak variasi maka hal tersebut menunjukkan tingginya risiko ketidakpastian return atas investasi tersebut. Investasi yang efisien merupakan investasi yang memberikan keuntungan besar dengan tingkat risiko tertentu atau terkecil. Varian return dalam hal ini dapat dikatakan mewakili risiko saham yang dapat mempengaruhi besar kecilnya bid ask spread saham.

Farida (2013) menyatakan bahwa risiko saham yang tinggi menyebabkan para pelaku pasar modal berusaha menanggulanginya dengan menentukan spread yang lebih besar. Sehingga risiko saham yang tinggi dapat tertutupi oleh harga spread yang besar sebagai kompensasi dari ketidakpastian return dari saham tersebut.

\section{PENELITIAN TERDAHULU}

Yulianto 2014 dengan penelitiannya Pengaruh Harga saham, Volume Perdagangan, Leverage, dan Likuiditas terhadap Bid Ask Spread Pada Perusahaan yang Terdaftar di Jll Periode 2010-2013. Harga saham dan leverage memiliki pengaruh negative terhadap bid ask spread saham syariah, sedangkan volume perdagangan memiliki pengaruh positif terhadap bid ask spread saham syariah, dan likuiditas tidak berpengaruh terhadap bid ask spread saham syariah.

NAPITULU DAN SYAHYUNAN 2013 dengan penelitiannya Pengaruh Return saham,
Volume Perdagangan, dan Volatilitas Harga Terhadap Bid ask spread Pada Perusahaan yang Melakukan Stock Split di BEl Periode 2010-2012. Secara simultan return saham, volume perdagangan, dan volatilitas harga saham berpengaruh positif signifikan terhadap bid ask spread pada perusahaan yang melakukan stock split di BEl. Sedangkan secara parsial, hanya return saham saja yang berpengaruh positif signifikan terhadap bid ask spread pada perusahaan yang melakukan stock split di BEl.

\section{Hipotesis}

$\mathrm{H}_{1}$ :Harga Sahamberpengaruh signifikan terhadap bid ask spread saham syariah perusahaan property dan real estate yang terdaftar di ISSI periode 2014 - 2017. $\mathrm{H}_{2}$ :Earning Per Share berpengaruh tidak signifikan terhadap bid ask spread saham syariah perusahaan property dan real estate yang terdaftar di ISSI periode 2014 2017.

$\mathrm{H}_{3}$ :Varian Return berpengaruh signifikan terhadap bid ask spread saham syariah perusahaan property dan real estate yang terdaftar di ISSI periode 2014 - 2017.

\section{METODE PENELITIAN}

Pendekatan yang digunakan dalam penelitian ini adalah pendekatan kuantitatif karena data yang ada di interpretasikan melalui angka - angka dan diolah secara statistik. Penelitian kuantitatif merupakan penelitian yang menitikberatkan pada pengujian hipotesis, pengukuran data, dan pembuatan 
Briliantini, et al/Jurnal Ekonomi Syariah Teori dan Terapan Vol. 6 No. 8 Agustus 2019: 1537-1552; ANALISIS HARGA SAHAM DAN EARNING PER SHARE (EPS) TERHADAP BID ASK SPREAD PADA SAHAM SYARIAH PERUSAHAAN PROPERTY DAN REAL ESTATE YANG TERDAFTAR DI ISSI PERIODE $2014-2017$

kesimpulan. Jenis penelitian yang digunakan dalam penelitian ini adalah penelitian deskriptif dengan pendekatan kuantitatif. Menurut Sugiyono (2012:7) metode kuantitatif merupakan metode penelitian yang berlandaskan pada filsafat positivisme, digunakan untuk meneliti populasi atau sampel tertentu, teknik pengambilan sampel dilakukan secara random, pengumpulan data menggunakan instrumen penelitian, analisisi data bersifat statistik dengan tujuan untuk menguji hipotesa yang telah ditetapkan.

\section{Identifikasi Variabel}

Penelitian kuantitatif dalam melihat hubungan variabel terhadap obyek yang diteliti lebih bersifat sebab dan akibat (kausal), sehingga dalam penelitian ini menggunakan dua jenis variabel yaitu variabel independen (variabel bebas) dan variabel dependen (variabel terikat). Sugiyono, (2011 : 39) menjelaskan bahwa variabel independen (variabel bebas) adalah variabel yang mempengaruhi atau yang menjadi sebab perubahannya atau timbulnya variabel dependen, sedangkan variabel dependen (terikat) adalah variabel yang dipengaruhi atau yang menjadi akibat, karena adanya variabel bebas.

\section{Populasi dan Sampel}

Populasi merupakan sekumpulan individu sejenis yang berada pada wilayah dan waktu tertentu. Menurut Sugiyono (2014:80) populasi adalah wilayah generalisasi yang terdiri atas obyek atau subyek yang mempunyai kualitas dan karakteristik tertentu yang ditetapkan dan dipelajari untuk kemudian ditarik kesimpulan. Populasi dalam penelitian ini adalah semua perusahaan property dan real estate yang terdaftat di Indeks Saham Syariah Indonesia pada periode2014-2017.

Sampel menurut Sugiyono (2014:81) adalah bagian populasi yang memiliki karakteristik tertentu. Pengambilan sampel dalam penelitian ini menggunakan teknik purposive sampling. Teknik purposive sampling itu sendiri merupakan teknik pengambilan sampel yang mana setiap elemen dari populasi tidak memiliki kesempatan yang sama untuk dipilih sebagai sampel (Silalahi, 2009:259). Kriteria penetapan sampel dalam penelitian ini berdasarkan hal berikut :

1. Perusahaan property dan real estate yang listed di ISSI dan tidak mengalami proses delisting selama periode 20142017

2. Perusahaan property dan real estate yang telah menerbitkan laporan kevangan secara lengkap pada periode 2014-2017.

\section{Pengumpulan Data}

Prosedur pengumpulan data yang digunakan pada penelitian ini adalah sebagai berikut :

a. Studi kepustakaan (Library research) Mengumpulkan berbagai informasi, teori, jurnal dan literature yang 
mempunyai relevansi dengan

permasalahan penelitian.

b. Penelitian terdahulu

Melakukan peninjauan dan penelitian secara umum untuk memperoleh informasi mengenai permasalahan yang dibahas dalam penelitian ini.

c. Pengumpulan data

Data penelitian diperoleh dari datadata sekunder yang diperoleh dari situs resmi perusahaan masing - masing, website resmi Bursa Efek Indonesia dan website resmi Otoritas Jasa Keuangan.

\section{Teknik Analisis Data}

Teknik analisis data pada penelitian ini menggunakan analisis regresi data panel. Data panel sendiri merupakan gabungan data time series dengan data cross section. Griffith (2001 : 351) menyatakan bahwa metode data panel merupakan metode yang tepat untuk mengatasi interkorelasi diantara variabel - variabel bebas yang dapat mengakibatkan tidak tepatnya penafsiran regresi. Penelitian ini menggunakan analisis data panel karena di dalam penelitian ini terdapat penggabungan dua data yaitu cross section (beberapa perusahaan property dan real estate yang terdaftar di ISSI) dan data time series( lingkup waktu selama beberapa tahun tertentu).

\section{Estimasi Regresi Data Panel}

Menurut Widarjono (2007:251)

terdapat tiga pendekatan dalam penelitian yang menggunakan teknik analisis data panel yaitu:

1. Common Effects Model (Pool least square)

Model pendekatan ini hanya mengkombinasikan data time series dan data cross section dalam betuk pool, dengan estimasi menggunakan kuadrat terkecil / pooled least square.

2. Fixed Effects Model

Pendekatan model ini mengasumsikan bahwa terdapat efek yang berbeda antar individu tetapi perbedaan itu dapat di diakomodasi melalui perbedaan yang ada pada intersepnya.

3. Random Effects Model (Error Component Model)

Model pendekatan ini menggunakan variabel gangguan (error terms). Model pendekatan ini mengestimasi data panel dimana variabel gangguan mungkin akan saling berhubungan di antar waktu dan antar individu.

\section{Pemilihan Model Estimasi Regresi Data Panel}

Terdapat pengujian yang dilakukan untuk menentukan model mana yang paling tepat untuk digunakan dalam pengolahan data panel. Pengujian yang digunakan dalam penelitian ini adalah uji Chow, uji Hausman, dan uji Lagrange Multiplier. Fungsi pengujian dalam penelitian ini yaitu yang pertama uji Chow digunakan untuk memilih antara metode 
Briliantini, et al/Jurnal Ekonomi Syariah Teori dan Terapan Vol. 6 No. 8 Agustus 2019: 1537-1552;

ANALISIS HARGA SAHAM DAN EARNING PER SHARE (EPS) TERHADAP BID ASK SPREAD PADA SAHAM SYARIAH PERUSAHAAN PROPERTY DAN REAL ESTATE YANG TERDAFTAR DI ISSI PERIODE $2014-2017$

common effect model (CEM)atau fixed effect model (FEM). Yang kedua uji Hausman digunakan untuk memilih antara metode fixed effect model (REM) atau random effect model (REM), dan yang ketiga adalah uji Lagrange Multiplier yang digunakan untuk memilih antara metode common effect model (CEM)atau random effect model (CEM)

\section{HASIL DAN PEMBAHASAN}

Penelitian ini mengestimasi model bid ask spread dengan menggunakan regresi data panel yang dilakukan dengan beberapa uji. Seperti yang telah dikemukakan sebelumnya, terdapat tiga model estimasi pada data panel yang terdiri dari Common Effect Model (CEM) / Pooled Least Square (PLS), Fixed Effect Model (FEM), dan Random Effect Model (REM). Untuk mendapatkan model estimasi terbaik, perlu dilakukan beberapa pengujian. Langkah pertama untuk mendapatkan model yang sesuai adalah dengan melakukan uji Chow. Uji Chow digunakan untuk memilih model estimasi terbaik antara Common Effect Model (CEM) dan Fixed Effect Model (FEM). Selanjutnya atau langkah kedua yang dilakukan adalah uji Hausman, uji Hausman dilakukan untuk memilih model terbaik antara Fixed Effect Model (FEM) dan Random Effect Model (REM). Langkah terakhir adalah uji Lagrance Multiplier, uji Lagrance Multiplier digunakan untuk memilih model estimasi terbaik antara Common Effect Model (CEM) / Pooled
Least Square (PLS) dengan Random Effect Model (REM).

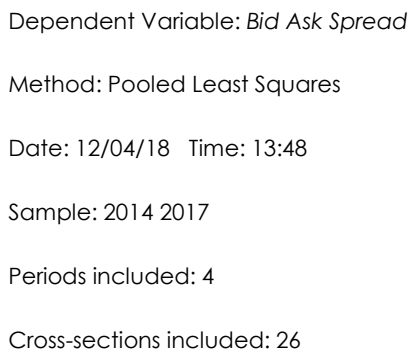

\begin{tabular}{|c|c|c|c|c|}
\hline \multicolumn{5}{|c|}{ Coefficien } \\
\hline Variable & $\dagger$ & Std. Error & t-Statistic & Prob. \\
\hline C & 4332.425 & 172.5189 & 25.11276 & 0.0000 \\
\hline $\mathrm{X} 1$ & -0.143134 & 0.052579 & -2.722275 & 0.0077 \\
\hline$\times 2$ & 0.130307 & 0.970990 & 0.134200 & 0.8935 \\
\hline$x 3$ & 0.000325 & 0.000259 & 1.252974 & 0.2131 \\
\hline R-squared & 0.187068 & Mean dep & endent var & 4111.277 \\
\hline Adjusted R-squared & 0.162680 & S.D. deper & dent var & 1628.586 \\
\hline S.E. of regression & 1490.241 & Akaike info & criterion & 17.48897 \\
\hline Sum squared resid & $2.22 \mathrm{E}+08$ & Schwarz Cl & terion & 17.59067 \\
\hline Log likelihood & -905.4262 & Hannan-Q & jinn criter. & 17.53017 \\
\hline F-statistic & 7.670517 & Durbin-Wa & son stat & 1.570392 \\
\hline Prob(F-statistic) & 0.000115 & & & \\
\hline
\end{tabular}

Parsial

Kriteria dalam penerimaan $\mathrm{H}_{0}$ dan $\mathrm{H}_{1}$ adalah dengan melihat nilai probabilitas ( $p$-value) dari masing masing variabel. Jika nilai probabilitas lebih kecil dari 0,05 maka $\mathrm{H}_{0}$ ditolak dan $\mathrm{H}_{1}$ diterima. Begitu sebaliknya, jika nilai probabilitas lebih besar dari 0,05 maka $\mathrm{H}_{0}$ diterima dan $\mathrm{H}_{1}$ ditolak. Berdasarkan hasil pengujian dengan model estimasi common effect model (CEM) / Pooled 
Briliantini, et al/Jurnal Ekonomi Syariah Teori dan Terapan Vol. 6 No. 8 Agustus 2019: 1537-1552;

ANALISIS HARGA SAHAM DAN EARNING PER SHARE (EPS) TERHADAP BID ASK SPREAD PADA SAHAM SYARIAH PERUSAHAAN PROPERTY DAN REAL ESTATE YANG TERDAFTAR DI ISSI PERIODE $2014-2017$

Least Square (PLS) pada tabel diatas, maka hasil uji $\dagger$ dapat diambil keputusan hipotesis sebagai berikut:

1. Nilai konstanta sebesar 4332,425 menunjukkan apabila variabel harga saham, earning per share (EPS), dan varian return besarnya nol atau konstan, maka nilai bid ask spread adalah sebesar 4332,425.

2. Variabel harga saham memiliki nilai probabilitas sebesar 0,0077 lebih kecil dari tingkat signifikansi $5 \%(a=0,05)$ sehingga $\mathrm{H}_{0}$ ditolak dan $\mathrm{H}_{1}$ diterima. Hal ini menunjukkan bahwa terdapat pengaruh signifikan antara Harga Saham terhadap Bid Ask Spread. Sedangkan nilai koefisien variabel harga saham pada Tabel 4.8 adalah sebesar -0,143134 hal ini menunjukkan bahwa setiap kenaikan satu satuan harga saham maka bid ask spread akan mengalami penurunan sebesar 0,143134 dengan asumsi bahwa variabel yang lain adalah konstan. Dari penjelasan diatas dapat ditarik kesimpulan bahwa Harga Saham berpengaruh negative signifikan terhadap bid ask spread.

3. Variabel earning per share (EPS) memiliki nilai probabilitas sebesar 0,8935 lebih besar dari tingkat signifikansi $5 \%(a=0,05)$ sehingga $\mathrm{H}_{0}$ diterima dan $\mathrm{H}_{2}$ ditolak. Hal ini menunjukkan bahwa earning per share (EPS) memiliki pengaruh tidak signifikan terhadap Bid Ask Spread saham syariah perusahaan property dan real estate yang terdaftar pada Indeks Saham Syariah Indonesia (ISSI) periode 2014 - 2017. Sedangkan nilai koefisien variabel earning per share (EPS) pada Tabel 4.8 adalah sebesar 0,130307 hal ini menunjukkan bahwa setiap kenaikan satu satuan earning per share (EPS) akan meningkatkan bid ask spread sebesar 0,130307 dengan asumsi bahwa variabel yang lain adalah konstan. Dari penjelasan diatas dapat ditarik kesimpulan bahwa earning per share (EPS) berpengaruh positif tidak signifikan terhadap bid ask spread.

4. Variabel varian return memiliki nilai probabilitas sebesar 0,2131 lebih besar dari tingkat signifikansi $5 \%(a=0,05)$ sehingga $\mathrm{H}_{0}$ diterima dan $\mathrm{H}_{3}$ ditolak. Hal ini menunjukkan bahwa varianreturn memiliki pengaruh tidak signifikan terhadap Bid Ask Spread saham syariah perusahaan property dan real estate yang terdaftar pada Indeska Saham Syariah Indonesia (ISSI) periode 2014 - 2017. Sedangkan nilai koefisien variabel varian return pada Tabel adalah sebesar 0,000325 hal ini menunjukkan bahwa setiap kenaikan satu satuan varian return akan meningkatkan bid ask spread sebesar 0,000325 dengan asumsi bahwa variabel yang lain adalah konstan. Dari penjelasan diatas dapat ditarik kesimpulan bahwa varian 
Briliantini, et al/Jurnal Ekonomi Syariah Teori dan Terapan Vol. 6 No. 8 Agustus 2019: 1537-1552;

ANALISIS HARGA SAHAM DAN EARNING PER SHARE (EPS) TERHADAP BID ASK SPREAD PADA SAHAM SYARIAH PERUSAHAAN PROPERTY DAN REAL ESTATE YANG TERDAFTAR DI ISSI PERIODE $2014-2017$

return berpengaruh positif tidak signifikan terhadap bid ask spread.

\section{Simultan}

Kriteria dalam penerimaan $\mathrm{H}_{0}$ dan $\mathrm{H}_{1}$ adalah dengan melihat nilai probabilitas statistik F. Jika nilai probabilitas lebih kecil dari tingkat signifikan 5\% ( $a=$ $0,05)$ maka $\mathrm{H}_{0}$ ditolak dan $\mathrm{H}_{1}$ diterima. Begitu pula sebaliknya, jika nilai probabilitas lebih besar dari tingkat signifikan 5\% (a $=0,05)$ maka $\mathrm{H}_{0}$ diterima dan $\mathrm{H}_{1}$ ditolak. Berdasarkan hasil pengujian dengan model estimasi common effect model (CEM) / Pooled Least Square (PLS) pada Tabel diatas, dapat dilihat bahwa nilai probabilitas statistic $F$ sebesar 0,000115 yang berarti nilai ini lebih kecil dari tingkat signifikan 5\% ( $a=0,05)$, sehingga $H_{0}$ ditolak dan $H_{1}$ diterima. Dari penjelasan tersebut dapat disimpulkan bahwa secara simultan variabel harga saham, earning per share (EPS) berpengaruh signifikan terhadap variabel dependen, yaitu bid ask spread saham syariah perusahaan property dan real estate yang terdaftar pada Indeks Saham Syariah Indonesia (ISSI) periode $2014-2017$.

\section{PENUTUP}

\section{Simpulan}

Berdasarkan hasil analisis dan pembahasan tentang pengaruh harga saham, earning per share (EPS), dan varian return saham syariah perusahaan property dan real estate yang terdaftar pada Indeks Saham Syariah Indonesia
(ISSI) periode 2014 - 2017 yang telah dibahas pada bab sebelumnya, sehingga hasil penelitian dapat disimpulkan sebagai berikut:

1. Harga Saham secara parsial berpengaruh negatif signifikan terhadap bid ask spread saham syariah perusahaan property dan real estate yang terdaftar pada Indeks Saham Syariah Indonesia (ISSI) periode 2014 2017, pada tingkat signifikasi $5 \%$ ( $a=$ $0,05)$. Dengan demikian, apabila harga saham tinggi maka hal tersebut mencerminkan bahwa perusahaan tersebut dalam kondisi yang baik dan mengindikasikan bahwa saham tersebut diminati oleh para investor.

2. Earning Per Share (EPS) secara parsial berpengaruh positif tidak signifikan terhadap bid ask spread saham syariah perusahaan property dan real estate yang terdaftar pada Indeks Saham Syariah Indonesia (ISSI) periode 2014 2017, pada tingkat signifikasi $5 \%$ ( $a=$ $0,05)$.

3. Varian return secara parsial berpengaruh positif tidak signifikan terhadap bid ask spread saham syariah perusahaan property dan real estate yang terdaftar pada Indeks Saham Syariah Indonesia (ISSI) periode 2014 2017, pada tingkat signifikasi $5 \%$ ( $a=$ $0,05)$.

4. Variabel harga saham, earning per share (EPS), dan varian return secara simultan berpengaruh signifikan 
terhadap bid ask spread saham syariah perusahaan property dan real estate yang terdaftar pada Indeks Saham Syariah Indonesia (ISSI) periode 2014 2017, pada tingkat signifikasi $5 \%$ ( $a=$ $0,05)$.

\section{Saran}

Penelitian ini memiliki keterbatasan yaitu hanya menggunakan tiga variabel independen yang terdiri dari harga saham, earning per share (EPS) dan varian return. Kemudian pada penelitian ini hanya menggunakan 26 perusahaan property dan real estate yang terdaftar pada Indeks Saham Syariah Indonesia (ISSI) periode 2014 - 2017 sebagai sampel dengan rentang waktu penelitian yang relative pendek yaitu 4 tahun. Saran yang dapat disampaikan berdasarkan kesimpulan yang telah diuraikan diatas adalah sebagai berikut :

1. Bagi calon investor, yang akan melakukan investasi pada pasar modal hendaknya memperhatikan atau mempertimbangkan harga saham, karena harga saham sangat mencerminkan kondisi perusahaan yang akan digunkan untuk berinvetasi dan harga saham memiliki pengaruh yang cukup signifikan terhadap bid ask spread saham syariah.

2. Bagi investor, hendaknya memperhatikan atau mempertimbangkan perilaku bid ask spread saham syariah sebelum memperjual belikan saham syariah yang dimiliki.

3. Bagi peneliti selanjutnya, penelitian ini diharapkan dapat menjadi referensi pada penelitian selanjutnya sehingga saran yang dapat diberikan adalah:

a. Penelitian selanjutnya menggunakan emiten atau perusahaan yang terdaftar pada Daftar Efek Syariah (DES) atau Indeks Saham Syariah Indonesia (ISSI).

b. Memperbanyak sampel yang diteliti.

c. Memperpanjang waktu penelitian.

d. Menambah variabel independen lainnya yang berkaitan dengan bid ask spread.

\section{DAFTAR PUSTAKA}

Ambarwati. Sri Dwi Ari. 2008. Pengaruh return saham, volume perdagangan saham, varian return saham terhadap bid ask spread saham pada perusahaan manufaktur yang tergabung dalam Indeks LQ 45 tahun 2003 2005. Jurnal Siasat Bisnis. Vol. 12, No.1.

Ewijaya dan Nur Indriantoro. 1999. Analisis Pengaruh Pemecahan Saham terhadap Perubahan Harga Saham. Jurnal Riset Akuntansi Indonesia, 2(1):5365.

Griffith, W.E. 2001. Undergraduate Econometrics. Cetakan kedua. Jhon Willey and Sons, Inc.

Hidayat, Taufik. 2011. Buku Pintar Investasi Syariah.Jakarta : PT TransMedia 
Briliantini, et al/Jurnal Ekonomi Syariah Teori dan Terapan Vol. 6 No. 8 Agustus 2019: 1537-1552;

ANALISIS HARGA SAHAM DAN EARNING PER SHARE (EPS) TERHADAP BID ASK SPREAD PADA SAHAM SYARIAH PERUSAHAAN PROPERTY DAN REAL ESTATE YANG TERDAFTAR DI ISSI PERIODE $2014-2017$

Husnan, Suad. 2009. Dasar - dasar Teori Portofolio dan Analisis Sekuritas Edisi Keempat. Yogyakarta : LPP STIM YKPN.

Napitupulu, Veronica dan Syahyunan. 2013. Pengaruh Return Saham, Volume Perdagangan Saham, dan Volatilitas Harga Saham Terhadap Bid Ask Spread Pada Perusahaan yang Melakukan Stock Splitdi Bursa Efek Indonesia. Jurnal Media Informasi Manajemen, Vol 1 No. 2, April 2013.

Rasyidi, Leoni B. dan Yunika Murdayanti. 2013. Pengaruh asset size, closing price, likuiditas, varian return, dan volume perdagangan saham terhadap bid ask spread pada perusahaan real estate dan property yang terdaftar di BEI. Accounting Analysis Journal. Vol. 8, No.2.

Ryandono, Muhammad Nafikh H. 2009.

Bursa Efek dan Investasi Syariah. Jakarta : Serambi.

Sartono. Agus. 2001. Manajemen Kevangan Teori dan Aplikasi. Edisi Keempat. Yogyakarta : BPFE.

Stoll. Hans R. 1989. Infering The Component Of The Bid Ask Spread: Theory and Empiricial Test. The Journal of Finance. Vol.4, No. 1.

Sugiyono. 2012. Metode Penelitian Kuantitatif, Kualitatif dan R\&D. Cetakan ke-XVII.Bandung: Alfabeta.
Sugiyono. 2014. Metode Penelitian Bisnis. Bandung : Alfabeta.

Tambunan, Andy Porman. 2007. Menilai Harga Wajar Saham (Stock Valuation). Jakarta : PT Elex Media Komputindo.

Tandellin, Eduardus. 2010. Portofolio dan Investasi Teori dan Aplikasi. Yogyakarta : Kanisius

\section{SITUS RESMI}

https://www.ojk.go.id

http://www.idx.co.id 